\title{
Association between repetitive work and occupational cold exposure
}

\author{
Márcia Rosângela Buzanello ${ }^{\mathrm{a}, \mathrm{b}^{*}}$ and Antônio Renato Pereira Moro ${ }^{\mathrm{c}, \mathrm{d}}$ \\ ${ }^{a}$ Post-graduation Program in Production Engineering, Laboratory of Biomechanics, Federal \\ University of Santa Catarina, SC, Brazil; \\ ${ }^{b}$ Department of Physical Therapy, State University of West of Paraná, Cascavel, PR; \\ ${ }^{\mathrm{c}}$ Post-graduation Program in Production Engineering, Laboratory of Biomechanics, Federal \\ University of Santa Catarina, SC, Brazil; \\ ${ }^{d}$ Department of Physical Education, Laboratory of Biomechanics, Federal University of Santa Catarina, SC, \\ Brazil.
}

\begin{abstract}
Occupational cold exposure is an important risk factor that increases stress at work and can induce many health effects like diseases and symptoms related to cold, including work-related musculoskeletal disorders. The methodological procedures were performed to measure these environmental variables as recommended by the ISO 7726/85. For the analysis of repetitiveness was used the OCRA checklist and evaluation of musculoskeletal morbidity conducted by the Nordic Musculoskeletal Questionnaire. So the objective of this study was to investigate the correlation between cold environmental variables and prevalence of musculoskeletal morbidity in the repetitive work. Was found association between work in cutting and boning sector (occupational cold and repetitive work) and the presence of musculoskeletal morbidity, with a significance of $99 \%$.
\end{abstract}

Keywords: Artificial cold, Nordic Musculoskeletal Questionnaire, OCRA

\footnotetext{
* Correponding author. Email: mrbuzanello@yahoo.com.brBrazil, General Rondon, 1559, Zip code 85901-160, Toledo, PR, Brazil
} 


\section{Introduction}

The Brazilian poultry industry was one of sectors of economy that has undergone profound changes in the last 40 years, leaving the familiar and traditional production, for the poultry industrial one, Dalla Costa [1]. According to UBABEF [13] Dalla Costa [2], Avicultura do Paraná [5] with the national poultry industry on the rise there is also a consequent increase in the need of industrialization and slaughter of poultry, as well as the demand for workers in the sector. Once the food processing industry must meet strict standards of regulation in relation to internal environmental temperatures, that may conflict with the health of workers. To Hunter, Kerr and Whillians [11] occupational cold exposure is an important risk factor that increases stress at work and can induce many health effects include diseases and symptoms related to cold, including work-related musculoskeletal disorders. Likewise psychosocial stressors at work, including psychological burden of work, working conditions, inadequate and monotonous work, were also related to increased this risk Walker-Bone and Cooper [12], Elfering, Grebner, Gerber and Semmes [3]. Thus exposure to cold working environment is a significant risk and represents the adverse effects on human comfort, health and performance.

So the objective of this study was to investigate the correlation between cold environmental variables and prevalence of musculoskeletal morbidity in the repetitive work.

\section{Methodology}

This study was regarded as field research, conducted in a poultry slaughterhouse of the western region of Paraná - Brazil. The sample was composed for 572 workers exposed to artificial occupational cold, belonging to sectors: refrigerator, cutting and deboning, drip and industrialized, divided into 19 subsectors. For the analysis of repetitiveness, the workers were videotaped for one minute performing their activities using the criterion of the OCRA checklist [8] to classify them.

Were analyzed the combination of several environmental variables that influence the thermal environment: air temperature, air velocity, relative humidity and temperature's of the hand and product. The methodological procedures were performed to measure these environmental variables as recommended by the ISO $7726 / 85$ [10], using the following instruments: a digital anemometer, hygrometer with a dual function (humidity and air temperature) and a minitermometer surface. And the evaluation of musculoskeletal morbidity conducted by the Nordic Musculoskeletal Questionnaire proposed by Dickison, Campion, Foster, Newman and Thomas O'Rourke [6].

The statistical analysis was used for categorical data correlation chi-square to verify the relationship of independent variables (air velocity, air temperature, air humidity, temperature of the hand and the product) and the existence of musculoskeletal morbidity in the various sectors.

\section{Results and Discussion}

According recommended by the OCRA checklist [8], the work in the poultry slaughterhouse analyzed was classified as repetitive. Based on the results obtained, it was found that predominance in the cutting and boning was 254 men and 42 women, age average among the four sectors was 24.98 the lowest and the biggest about the freezing sector 26.30 years old.

In relation to time working in the artificial cold environment, it was found a mean of 21.78 months in the cutting and boning. Almost the same as the industrialized 21.89 months. Of the workers sampled per sector, $51.74 \%$ belong to the sector cutting and boning.

Regarding complaints of pain and discomfort in the last month and the last year. Of the 296 of cutting and boning, 128 workers had it in the hands and wrists, shoulders and lumbar and cervical spine. Demonstrating a high prevalence of complaints in this sector with artificial cold exposure.

Was found association between working in cutting and boning sector (occupational cold and repetitive work) and the presence of musculoskeletal morbidity, with a significance of $99 \%$. This sector is the development of the cuts, which require the use of larger and repetitive manual labor, making minimal use of machinery. And thus incorporating into the production process of this sector mainly manual task, where the tool is started exclusively by muscular contraction of the worker.

The prevalence of symptoms and musculoskeletal complaints among workers in a meat processing company showed that workers most heavily exposed to cold $\left(+2^{\circ} \mathrm{C}\right)$ had higher prevalence ratios of complaints in the shoulder, wrist / hand and lumbar spine 
(3.36, 2.57 and 2.24 respectively) compared to less exposed workers $\left(+9^{\circ} \mathrm{C}\right)$ Piedrahita et al [9]. Studies involving the exposure to cold ocupcional and repetitive stress injuries are scarce and often contradictory, especially there is a lack of laboratory studies.

\section{Conclusion}

There is a necessity for more research about work in the artificial cold in Brazil, as well as laboratory studies. Main especially associating workload and cold.

\section{Acknowledgements}

Thanks to UNIOESTE and UFSC for financial help.

\section{References}

[1] A. Dalla Costa. (2008). Contratos, novas tecnologias e produtividade do trabalho entre os avicultores do Sul do Brasil. Revista Brasileira de inovação. 7 (2), p.313-340, jul/dez.

[2] A. Dalla Costa. Avicultura brasileira. Acessed in: 2010, dec 02 Retrieved from: http://www.agronet.com.br/avicultura1.htm.

[3] A. Elfering, S. Grebner, H. Gerber and N.K. Semmer. Workplace observation of work stressors, catecholamines and musculoskeletal pain among male employees. Scand J Work Environ Health, 34(2008), 337-344.
[4] A.T. Rizzi. Mudanças Tecnológicas e Reestruturação da Indústria Agroalimentar: o caso da indústria de frangos no Brasil. Doctoral Tesis, Universidade Estadual de Campinas UNICAMP, 1993.

[5] Avicultura do Paraná. Setor avícola discute Norma Regulamentadora para trabalhadores de frigoríficos. Acessed in: 2010, dec $02 . \quad$ Retrieved from: http://www.ubis.com.br/clientes/adv/sindiavipar/pdfs/19 edicao. pdf. Pg38-39.

[6] C. E. Dickison, K. Campion, A. F. Foster, S. J. Newman, A. M. T. O'Rourke and P.G. Thomas. Questionnaire development: an examination of the Nordic Musculoskeletal Questionnaire. Applied Ergonomics. 23 (1992),19-23, June.

[7] D. Colombini and E. Occhipinti, Risultati della valutazione del rischio e del danno in gruppi di lavoratori esposti, in diversi comparti lavorativi, a movimenti e sforzi ripetuti degli arti superiori, La Medicina Del Lavoro 95 (2004), 233-246.

[8] D. Colombini, E. Occhipinti and M. Fanti, Método Ocra para análise e a prevenção do risco por movimentos repetitivos: manual para a avaliação e a gestão do risco, LTr, São Paulo, 2008

[9] H. Piedrahita, J.Oksa, H. Rintamäki, E.Sormunen and C. Malm. Effect of cooling on upper limb trajectories during a repetitive lifting task. In: Proceedings of the IEA 2006 Congress. Pikaar R, Koningsveld E, Settle P Editors. Elsevier Ltd. Maastricht (The Netherland). July 10-14, 2006.

[10] ISO 7726. Thermal environments - Instruments and methods for measuring physical quantities. International Organization for Standardization. New York, 1998.

[11] J.Hunter, E.H.Kerr and M.G. Whillians. The relation between joint stiffness upon exposure to cold and the characteristics of the synovial fluid. Can J Med Sci, 30(1952), 367-377.

[12] K. Walker-Bone and C. Cooper. Hard work never hurt anyone - or did it? A review of occupational associations with soft tissue musculoskeletal disorders of the neck and upper limb. Ann Rheum Dis, 64(2005), 1112-1117.

[13] UBABEF - União Brasileira de Avicultura. Exportações brasileiras de carne de frango. Acessed in: 2010, dec 10. Retrieved from: http://www.abef.com.br 